\title{
Memories of a great man, Ivan Málek
}

\author{
Arnold L. Demain · Jaroslav Spizek
}

(C) Society for Industrial Microbiology 2010

Ivan Málek was a great scientist and an inspiration to Czech scientists and to microbiologists and biochemical engineers around the world. He brought Czech microbiology into the world of science and medicine. His devotion to continuous fermentation was recognized throughout the world. Despite the German occupation of Czechoslovakia during World War II, Málek worked on autovaccination therapy and was able to produce small amounts of penicillin, which was used to treat ill patients. He was a prolific writer of microbiological textbooks including Microbiology and Epidemiology (1946), Laboratory Methods for Bacteriological Diagnosis (1948), Fight of Modern Science Against Microorganisms (1951) and General Medical Microbiology (1953).

It was in 1945 that, as a microbiologist and physician, he was appointed Lecturer at Charles University. A year after that, he went to Connaught Laboratories at the University of Toronto to study methods of penicillin production. This led to the establishment in 1949 of the first Czechoslovak penicillin factory in Roztoky u Prahy, a suburb of Prague. After his return from Canada, Málek lectured and taught more than 1,500 students studying medicine or nursing. In 1947, he established the country's first school of medical laboratory technology. Málek became Associate Professor in 1948 and published his paper on variability of bacteria. In that same year, he taught and helped organize research at the new School of Medicine in Hradec Kralove. He also

A. L. Demain $(\varangle)$

Charles A. Dana Research Institute for Scientists Emeriti (RISE),

Drew University, Madison, NJ 07940, USA

e-mail: ademain@drew.edu

J. Spizek

Institute of Microbiology, Academy of Sciences of the Czech

Republic (ASCR), 14220 Prague 4, Czech Republic continued his work on continuous fermentation and returned to an early interest in mycobacteria. When the country formed an Academy of Sciences (ASCR) made up of research institutes in natural and social sciences in 1950, Málek was called upon to become the Director of the Central Institute of Biology in Prague and the Chairman of the Czechoslovak Society for Microbiology. He was soon elected to the ASCR and appointed as Chairman of the Central Institute of Biology. He helped found the journal Folia Microbiologica in 1956 and became the first Director of the Institute of Microbiology which was spun off from the Central Institute of Biology. This new institute, which soon became famous around the world for its first-rate research, was established in a new building in $\mathrm{Krc}$, a district of Prague. He continued his work on continuous fermentation and established the importance of the "physiologic state" of microbiological populations. He was instrumental in the annual sending of ten or more Institute scientists to various laboratories in the USA and Western Europe. This is the way that many of us became familiar with excellent Czech scientists in our laboratories and those of our colleagues. Málek also arranged for foreign scientists to do their sabbatical leave research at the Institute of Microbiology. He was always willing to help the Institute's scientists and technicians to overcome their difficult problems of life and existence. Quite often he served as an umbrella, kindly covering their more or less frequent acts of misconduct against an oppressive regime.

Of great interest to Málek was the setting up of international meetings. After organizing the First International Symposium on the Continuous Cultivation of Microorganisms in Prague in 1958, the Proceedings were published by the ASCR and became well known around the world. This was followed by later Symposia in Prague in 1962, Porton Down, UK in 1966, Prague in 1968, and Oxford in 
1971 and 1975. The text Theoretical and Methodological Basis of Continuous Culture of Microorganisms was written by Málek and Fencl in 1966 and published in four languages.

Despite the great successes of Málek in making Czechoslovakia a world leader in microbial fermentations, doom came in 1968 with the invasion of Czechoslovakia by the USSR.

In 1969, Ivan Málek's 60th birthday was celebrated in Dobris Castle near Prague. On this occasion, a collection of papers called Ideas of Pupils about Science was published, edited by Miroslav Holub, a well-known immunologist and poet. Pupils and Institute scientists contributed to their kind teacher by quoting famous past scientists such as Galileo Galilei, Louis Pasteur, Albert Schweitzer, Aldous Huxley, and Tomas Garigue Masaryk, the first president of Czechoslovakia and great humanist, and by their own ideas and short poems. At that time, Ivan Málek was still allowed to take part in such an event in his honor. He was full of optimism and referred to a Czech poet Jiri Mahen: "In the darkest nights, think of the sun", and concluded by writing: "Let us open with the utmost effort all the springs of viva aqua for the new, brighter future". However, this was his last public performance for many years to come.

The Communist Party forced him into house arrest soon after. He was banned from research in 1970 and was prohibited from having contact with Western scientists. One of us (A.L.D.) first met Ivan Málek during attendance at the 1970 International Symposium on the Genetics of Microorganisms in Prague in 1970. It was the first GIM meeting, and I was invited to give the Closing Plenary Lecture. It was at this meeting that I began friendships with so many wonderful Czech scientists, such as Zdenko Vanek, Margita Blumaerova, Jarda Spizek, Zdanek Hostalek, Vladimir Behal and Irena Komersova (who recently passed away). Despite the ban, I was able to meet Málek and become a fan of his devotion to the field. He was not allowed to speak at the 1971 Continuous Culture Symposium in Oxford. He was replaced as Director of the Institute of Microbiology by a politician, a member of the Communist Party. I can vividly remember meeting the "Director" in his office and was somewhat shocked by his framed photographs of Lenin and Stalin, the only ones on the wall. On subsequent visits to Prague, I visited Málek in his home despite the ban on foreign contacts; he was brave enough to do this. In 1980, when politics eased the control of Málek by the Communist Party, he was allowed to speak at the 6th International Fermentation Symposium in London, Ontario. We were both invited to give lectures. I met him there and was delighted to spend much time with him. We were both at the head table during the banquet and had excellent conversations about microbiology, Czechoslovakia and people. Málek was also allowed to speak at Porton in 1982 on the "Continuous Cultivation of Microorganisms-Ecological Significance of Physiological State Studies". In 1983, he spoke at the Nobel Symposium in Stockholm.

Ivan Málek devoted much of his time and energy to the advancement of science. He was the recipient of the Purkyne Medal of the ASCR. His efforts were appreciated by many international organizations. His appointments included the committee of the International Atomic Energy Association, and memberships in the German Academy of Natural Sciences "Leopoldina", the German Academy of Sciences, the Bulgarian Academy of Sciences, the Fermentation Section of the International Union of Pure and Applied Chemistry, the UNESCO International Cell Research Organization Panel on Applied Microbiology, the American Association for the Advancement of Science, the New York Academy of Sciences, the World Academy of Arts and Science in Rome and Honorary Membership of the American Society for Microbiology. He was also Vice President of the Executive Committee of the International Union of Biological Sciences. He believed strongly in world peace, joining the Pugwash Movement for World Peace and Stability in 1962 and serving on the Governing Board of the Stockholm International Peace Research Institute for 10 years. Ivan Málek was a great, highly educated personality. He was fluent in five languages. He was not only a very good piano player but also composed his own pieces. He was also an enthusiastic sportsman who never missed the Institute's volleyball matches.

Since his passing away in 1994, we have sorely missed Ivan Málek. We think of him often and remember his greatness as a person, as a "survivor" and as a great microbiologist. We are pleased to be able to contribute to the special issue devoted to this great man.

Acknowledgments We are indebted to Zdenko Vanek for providing much of the information on the life of Ivan Málek in his article titled "Ivan Málek (1909-1994): Medical scientist and leader of post-war Czechoslovak microbiology" (published in SIM News, 53:164-168, 2003). 